\title{
Vulnerability of the agricultural systems of Argentina to climate change
}

\author{
Graciela O. Magrin*, María I. Travasso, Raúl A. Díaz, Rafael O. Rodríguez
}

Instituto de Clima y Agua, Centro de Investigaciones en Recursos Naturales, Instituto Nacional de Tecnología Agropecuaria, 1712 Castelar, Buenos Aires, Argentina

\begin{abstract}
Agricultural production is one of the pillars of the Argentinean economy. The contribution of this sector is expected to keep growing in the near future as a consequence of the current technological development trend. However, the projected changes in climate and in the atmospheric concentration of $\mathrm{CO}_{2}$ in the coming years is likely to affect the productivity of crops, thus causing an impact on the national economy. This paper addresses climate change impact on the production of the main crops of the Argentinean pampean region by means of crop growth and development simulation models for wheat, maize and soybean included in DSSAT v. 3.0 (Dension Support System for Agrotechnology Transfer, Univ. of Hawaii, Honolulu). The weather data used includes temperature, global solar radiation and precipitation values from 23 sites within the region (current climate conditions) and the corresponding GISS general circulation model projections for the year 2050 (future climate) with $\mathrm{CO}_{2}$ concentrations of 330 and $550 \mathrm{ppm}$ respectively. According to the results obtained, a generalized increase in soybean yield and a decrease in maize yield would occur. Wheat yield is likely to increase in the southern and the western parts of the region and decrease towards the north. Wheat and soybean production in the pampean region would increase by 3.6 and $20.7 \%$ respectively, while maize production would be reduced by $16.5 \%$.
\end{abstract}

KEY WORDS: Climate change $\cdot$ Argentina $\cdot$ Models $\cdot$ Wheat $\cdot$ Maize $\cdot$ Soybean

\section{INTRODUCTION}

Global climate change, caused mainly by an increase in atmospheric $\mathrm{CO}_{2}$ and other greenhouse gases, will affect the productivity of natural and cultivated ecosystems. The increase in $\mathrm{CO}_{2}$ will have positive direct effects on vegetation as a result of a higher net photosynthetic rate (Gifford \& Morison 1993) and water use efficiency. However, indirect effects related to climate change will also occur. According to IPCC (1990) projections, the Earth's temperature will rise 1.5 to $4.5^{\circ} \mathrm{C}$ by the middle of the 21 st century. General circulation models (GCMs) predict that this increase will be higher at high latitudes than at low latitudes (Rosenzweig \& Hillel 1995). Important changes in the precipitation and radiation

•E-mail: gmagrin@inta.gov.ar patterns are also predicted by the GCMs. Variations in the productivity of plant species would consequently occur. These variations would either be positive or negative, depending on the sensitivity of the soil-plant-climate system, which would be indicative of the degree of vulnerability.

Biological models, which simulate crop development and growth, are a valuable tool to assess vulnerability and to estimate the impact of climate change in different regions. The DSSAT v. 3.0 (Decision Support System for Agrotechnology Transfer) (IBSNAT 1994) is a system that integrates crop growth dynamic models with crop, weather and soil data and with application programs which allow for evaluating different strategies of agricultural production. The DSSAT v. 3.0 models can predict crop growth responses to the main yield-determining factors, i.e. climate (maximum and minimum temperature, precipitation and radiation), soil (physical and chemical properties), cultivar 

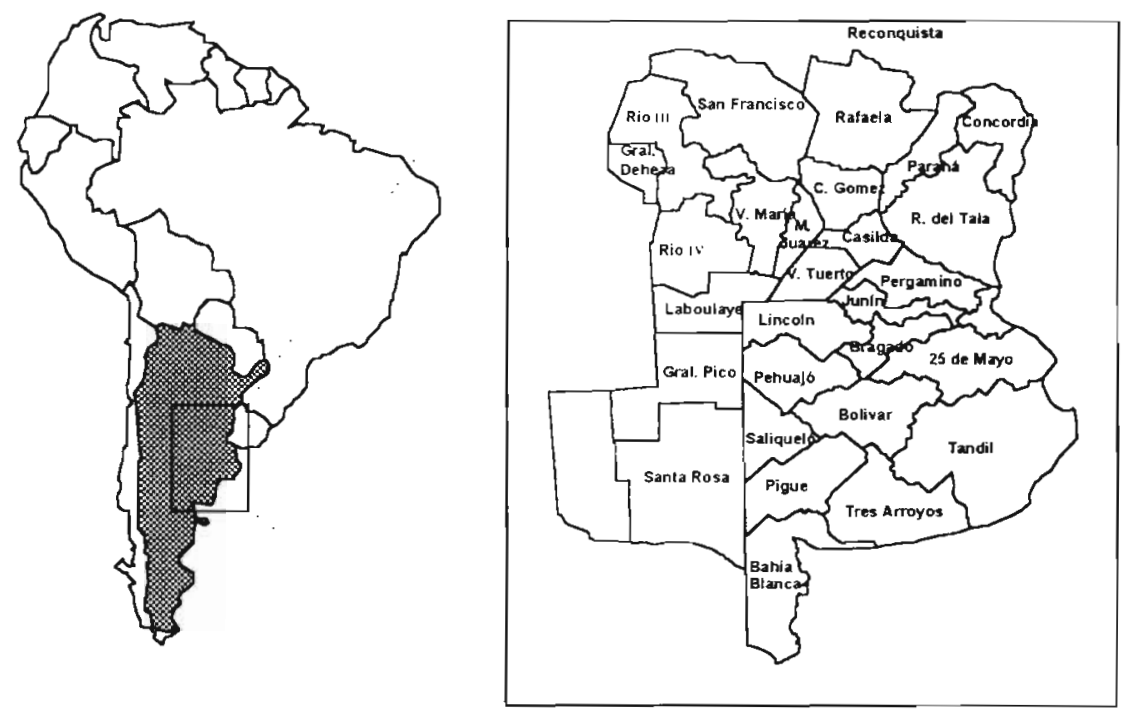

Fig. 1. Location of the Argentinean pampean region and the 29 districts considered for this study

(genetic characteristics) and management practices (planting date, fertilization, irrigation). They can also assess the effect of climate change and the direct effects of $\mathrm{CO}_{2}$ on crop growth.

Argentina is one of the most important countries in America for grain production and trade. The pampean region, a vast plain of 60 million ha, is the major production region. Twenty million ha are planted each year. The mean annual grain yield is 35 million $t$, but may range from 21 to 45 million t depending on interannual climate variability. Since approximately $50 \%$ of the crop production is exported, this sector represents one of the main socio-economic pillars of the country.

The pampean region lies between $30^{\circ}$ and $41^{\circ} \mathrm{S}$ latitude. The climate of the region is temperate-humidsubhumid, with occurrence of seasonal droughts. Annual precipitation values range from $1200 \mathrm{~mm}$ in the east to $600 \mathrm{~mm}$ in the west. The annual mean temperature is $17^{\circ} \mathrm{C}$ in the north and $14^{\circ} \mathrm{C}$ in the south. The agricultural production system basically consists of extensive rainfed production, which is heavily dependent on weather conditions.

During the last decade, agricultural production in the region has been particularly intensive as a consequence of a relative increase in prices (Basualdo 1995) as well as in rainfall (Hoffman 1989). Both factors have contributed to the enlargement of the planted area (by about $40 \%$ in the Buenos Aires province). Further, the agricultural boundaries have shifted towards the western part of the region. This process has caused an increase in the vulnerability of the natural resources.

Recently, an increase in the use of inputs (particularly fertilizers and fungicides) has added to the intensification of production, thus allowing higher yields to be obtained with no irrigation. This situation, which improves the income-yield expectations of the sector and the volume of exports, will not only amplify the impact of interannual climate oscillations on production, but will also magnify the effects of extreme climatic events (water excess and deficiency).

The goal of this study is to assess the vulnerability of wheat, soybean and maize production in the pampean region to the climate change conditions projected for the middle of the next century, and to estimate the impacts of such changes on the production capability of the region.

\section{MATERIALS AND METHODS}

\subsection{Study area}

The study area is the Argentinean pampean region, comprising the provinces of Buenos Aires, Entre Ríos, Santa Fé and Córdoba and the eastern part of La Pampa. The subdivisions made by the Secretaría de Agricultura y Ganadería for the regional assessment of grain and oilseed production was used for this study; it includes 29 districts (Fig. 1), corresponding to a grouping of 2 or more counties ('departamentos' or 'partidos') depending on the province. The number of districts are: 12 in the Buenos Aires province (Bahía Blanca, Bolivar, Bragado, Junín, Lincoln, Pehuajó, Pergamino, Pigué, Saliqueló, Tandil, Tres Arroyos and 25 de Mayo), 7 in Córdoba (Laboulaye, Marcos Juârez, Río IV, Río III, General Deheza, San Francisco and Villa María), 5 in Santa Fé [Cañada de Gómez, Casilda, Rafaela, Venado Tuerto and Avellaneda (Reconquista in Fig, 1)], 3 in Entre Ríos (Concordia, Paraná and Rosario del Tala) and 2 in La Pampa (General Pico and Santa Rosa). 


\subsection{Crop models}

The CERES-Wheat, CERES-Maize and CROPGRO (soybean) models from DSSAT v. 3.0 were used. They were first experimentally calibrated under non-limiting production conditions in order to characterize the cultivars most commonly sown in Argentina. These models had already been previously evaluated at 11 sites of the region under limiting production conditions. In that case a mean error in the yield estimate of $8 \%$ for wheat, $12.4 \%$ for maize and $13.5 \%$ for soybean was found (Magrin et al. 1991, Magrin 1994). In the case of wheat and maize, an additional calibration had been carried out for this region in order to evaluate the adjustment of the estimates at the county level. In that particular case the mean error of the estimate was $6.6 \%$ for wheat (Magrin 1994) and 10\% for maize (Boullon et al. 1996).

\subsection{Climatic scenarios}

Two scenarios were considered: current and future The current scenario was derived from daily radiation, maximum and minimum temperature and precipitation data recorded at a weather station from each of 23 different districts of the pampean region. The records from the closest station were used for the 6 remaining districts. The 1971 to 1994 time period was considered, with a $\mathrm{CO}_{2}$ concentration of 330 ppm.

The climate projections for the future scenario were derived from the general circulation model GISS (Goddard Institute for Space Studies; Hansen et al. 1988) on the basis of the same climate period and under a $\mathrm{CO}_{2}$ concentration of $550 \mathrm{ppm}$

\subsection{Yield and production}

The different models were used to estimate the yield for each crop under rainfed conditions, for the cultivar or hybrid most commonly sown and at the optimum planting date and density for each zone. The mean yield was simulated for the 1971 to 1994 period and under the 2 climatic scenarios at each district. The average production data were calculated for the average area planted annually at each district during the 1980 to 1990 period (obtained from official statistics) and considering the mean simulated yield for the current and the future climate at each district.

\section{RESULTS AND DISCUSSION}

\subsection{Wheat}

According to the climate projections derived from the GISS model, precipitation during the growth cycle of wheat crops will proportionally decrease over the region, while the maximum and minimum temperatures will generally increase. These climatic conditions combined with the direct effect of $\mathrm{CO}_{2}$ would cause wheat yields to increase by up to $15 \%$ in the southern part of the pampean region and to decrease in the same proportion in the north. The northern part of the Buenos Aires province (Fig. 2) represents the area of transition between both situations. However, the western part of the northern zone would also be subject to slight increases (between 0 and $5 \%$ ).

Rodríguez \& Fernández (1993) have observed a similar trend in the evolution of yield. The regions where yield is projected to increase are those where the lowest temperatures currently occur-particularly with regard to minimum temperature values - as a result of latitude, continental climate condition, and topography.

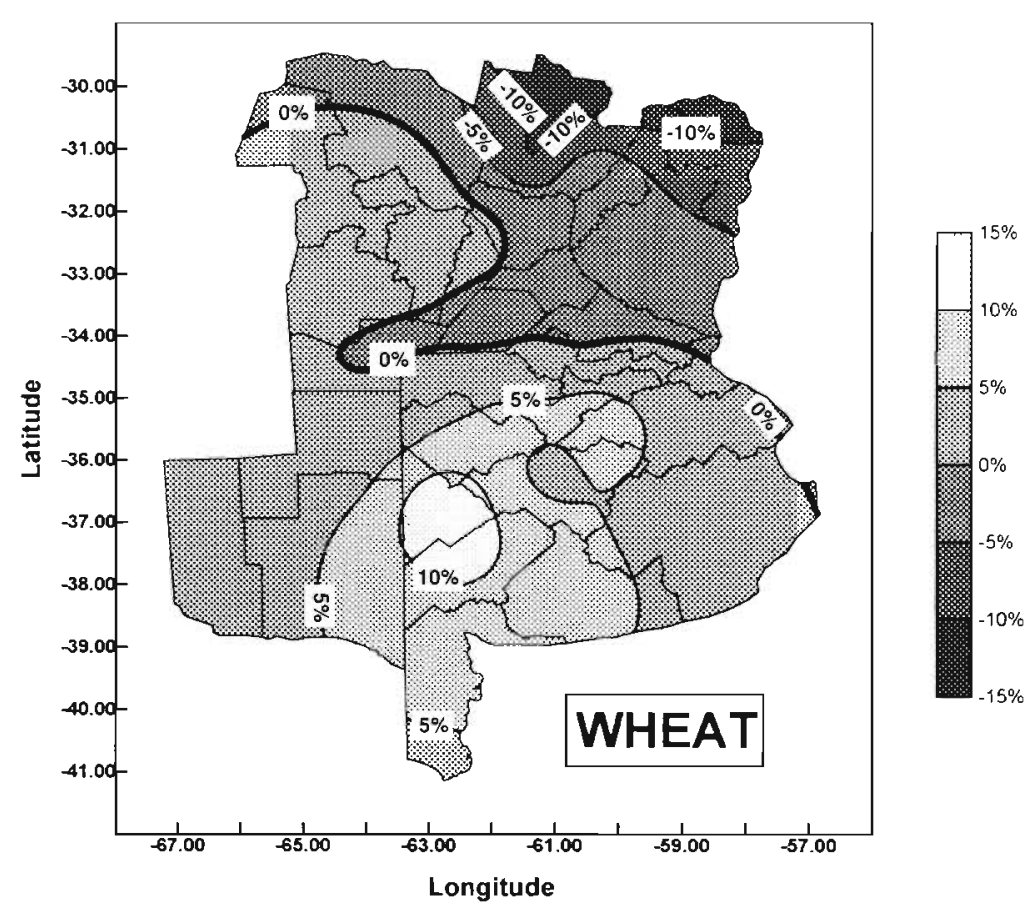

Fig. 2. Differences in percentage between CERES-Wheat simulated yields under the current and future climate scenarios for the Argentinean pampean region 
Results of an earlier study by Baethgen \& Magrin (1995) suggest that changes in temperature would be more significant than precipitation variations in this region.

The projected rise in temperature would accelerate the development rate, reducing the growth cycle by $24 \mathrm{~d}$ on average. The reduction would be proportionally higher during the planting-anthesis stage (22 d) than during the anthesis-maturity stage ( $2 \mathrm{~d}$ ). Thus, a generalized yield decrease would be expected as a consequence of a lower use of resources such as radiation. However, this process might either not take place or be reverted if the photosynthetic efficiency increases.

The predicted increases and reductions in yield suggest that temperature could also affect dry matter production, which might explain the differences encountered. The potential accumulation of biomass is dependent on solar radiation (Gallagher \& Biscoe 1978) and is likely to decrease under nutrient or watex limiting conditions or under unfavorable temperature conditions (Monteith 1981). According to the CERESWheat model the optimum day temperature for growth is $18^{\circ} \mathrm{C}$, with a decrease in biomass production when temperature values are higher or lower.

The effect of temperature on growth was assessed for 3 districts: Pigué (in southeastern Buenos Aires) and Río III (at the center of Córdoba), where yields are expected to increase, and Avellaneda (in northern Santa Fe), where yields are expected to decrease (Fig. 2). Minimum and maximum temperatures in these districts are projected to increase during the growth cycle by $3^{\circ} \mathrm{C}$ at Pigué and Río III and by $4^{\circ} \mathrm{C}$ at Avellaneda (Table 1). Therefore, the mean day temperature during the growth cycle (estimated as $25 \%$ of the minimum temperature and $75 \%$ of the maximum temperature) would be $17.7^{\circ} \mathrm{C}$ at Pigué, $19.9^{\circ} \mathrm{C}$ at Río III and $22.6^{\circ} \mathrm{C}$ at Avellaneda. The values during the vegetative stage would be $17.1,18$ and $21.6^{\circ} \mathrm{C}$, respectively.

In these districts yield variations are related to changes in biomass and in the number of grains per unit area (Table 2), as well as to increases in day temperature differentially affecting dry matter accumulation. The southernmost areas would have temperature conditions close to the $18^{\circ} \mathrm{C}$ optimum, while an increase in temperature in the north of the region would enhance unfavorable conditions.

Total wheat production in the pampean region would be favored by the predicted yield variations. According to the mean values obtained for each district during the 1980 to 1990 decade, the total planted area is estimated at about 5 million ha, with a mean yield of $1.83 \mathrm{t} \mathrm{ha}^{-1}$ and a total production of 9.15 million $\mathrm{t}$. According to the projected variations in yield and assuming that the planted area in each district remains unchanged, an increase in production by $325000 \mathrm{t}$ (3.6\%) would be expected. Mean yield would thus increase by $1.9 \mathrm{t} \mathrm{ha}^{-1}(4 \%)$. Pigué and Tres Arroyos districts (located in the south-southwestern part of Buenos Aires province) would be the major contributors to the total increase in production, while the highest losses would take place in Cañada de Gómez, Casilda and Rafaela districts (Santa Fé province).

\subsection{Maize}

Maize yields would decrease by 5 to $30 \%$ throughout the pampean region (Fig. 3) as previously stated by Paruelo \& Sala (1993) and R. O. Rodríguez, G. O. Magrin \& N. Fernandez (unpubl.). The lowest relative decreases ( 5 to $10 \%$ ) would occur in the north, and the highest (25 to $30 \%$ ) in the southeast. In the production nucleus or central zone (northern part of Buenos Aires, southern part of Santa Fé and eastern part of Córdoba) intermediate decreases would take place (10 to $20 \%$ ).

The cause of these decreases was analyzed for 4 districts: (1) Rafaela, in the northern sector of the region; (2) Junin and (3) Pergamino, both in the nucleus zone; and (4) Tandil, in the southeastern sector of the region. The predicted increase in temperature would cause a considerable reduction of the growth cycle duration.

Table 1. Minimum temperatures (mT) and maximum temperatures (MT), in ${ }^{\circ} \mathrm{C}$, during the growth cycle of wheat under the current and future climate scenarios for 3 districts of the pampean region of Argentina

\begin{tabular}{lcrcc|}
\hline District & $\begin{array}{c}\text { Current } \\
\mathrm{mT}\end{array}$ & $\begin{array}{c}\text { Future } \\
\mathrm{mT}\end{array}$ & $\begin{array}{c}\text { Current } \\
\mathrm{MT}\end{array}$ & $\begin{array}{c}\text { Future } \\
\mathrm{MT}\end{array}$ \\
\hline Pigué & 5.2 & 8.6 & 17.5 & 20.7 \\
Rio III & 6.1 & 9.2 & 20.3 & 23.4 \\
Avellaneda & 10.3 & 14.4 & 21.4 & 25.3 \\
\hline
\end{tabular}

Table 2. Wheat yield $\left(\mathrm{kg} \mathrm{ha}^{-i}\right)$, no. of grains $\mathrm{m}^{-2}, 1000$-grain weight $(\mathrm{g})$ and aboveground biomass ( $\mathrm{kg}$ dry matter ha- ${ }^{-1}$ ) for current $(\mathrm{Cu})$ and future $(\mathrm{Ft})$ climate scenarios in 3 cistricts of the pampean region of Argentina

\begin{tabular}{|c|c|c|c|c|c|}
\hline Districts & & Yield & $\begin{array}{c}\text { No. grains } \\
\mathrm{m}^{-2}\end{array}$ & $\begin{array}{c}1000 \text {-grain } \\
\text { weight }\end{array}$ & Biomass \\
\hline Pigué & $\begin{array}{l}\mathrm{Cu} \\
\mathrm{Ft}\end{array}$ & $\begin{array}{l}2470 \\
2740\end{array}$ & $\begin{array}{l}6770 \\
7740\end{array}$ & $\begin{array}{l}36.5 \\
35.4\end{array}$ & $\begin{array}{l}6290 \\
7130\end{array}$ \\
\hline Rio III & $\begin{array}{l}\mathrm{Cu} \\
\mathrm{Ft}\end{array}$ & $\begin{array}{l}1340 \\
1460\end{array}$ & $\begin{array}{l}3650 \\
4170\end{array}$ & $\begin{array}{l}36.6 \\
35.0\end{array}$ & $\begin{array}{l}3500 \\
3750\end{array}$ \\
\hline Avellaneda & $\begin{array}{l}\mathrm{Cu} \\
\mathrm{Ft}\end{array}$ & $\begin{array}{l}1915 \\
1465\end{array}$ & $\begin{array}{l}5040 \\
4100\end{array}$ & $\begin{array}{l}38.0 \\
35.7\end{array}$ & $\begin{array}{l}4520 \\
3540\end{array}$ \\
\hline
\end{tabular}




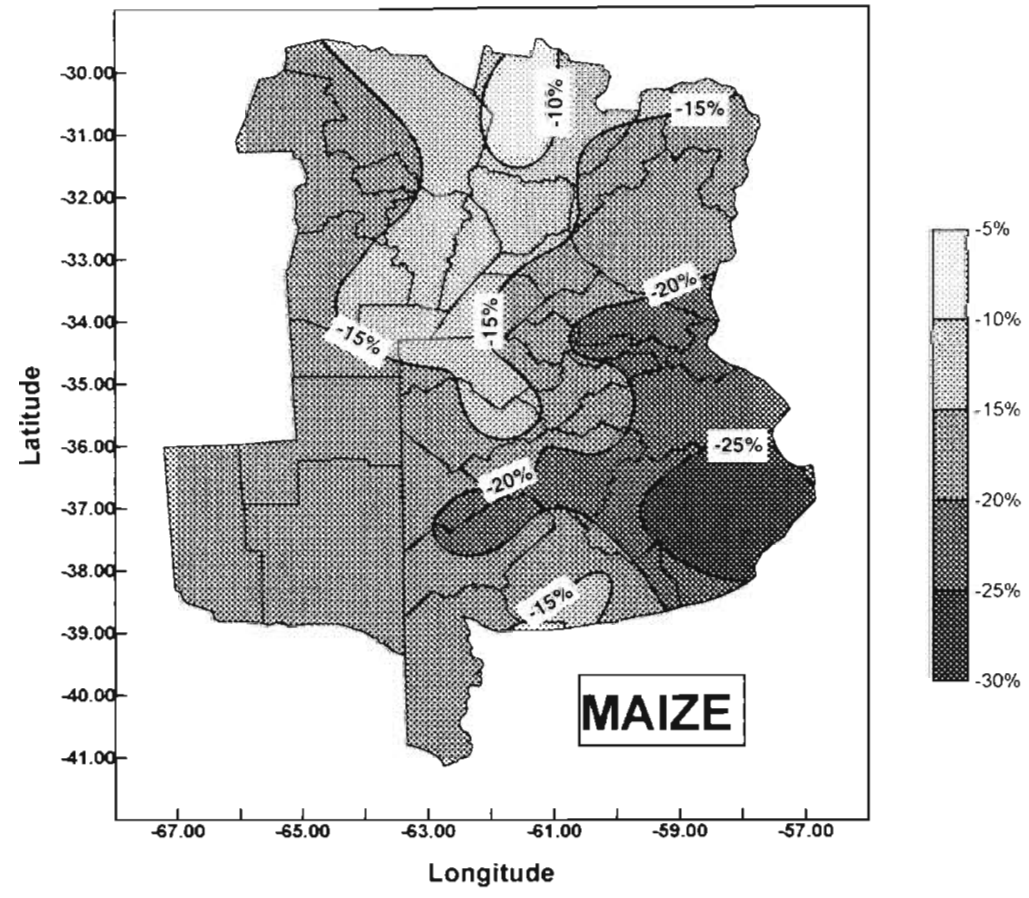

Fig. 3. Differences in percentage between CERES-Maize simulated yields under the current and future climate scenarios for the Argentinean pampean region

Significant differences in this behavior are expected to occur, depending on the latitude. The planting-anthesis stage would be, on average, $15 \mathrm{~d}$ shorter throughout the area, while the anthesis-maturity stage would be 5 d shorter in the northern sector, $11 \mathrm{~d}$ in the central zone or nucleus, and $20 \mathrm{~d}$ in the southeastern sector.

The analysis of yield components indicates that the number of grains per plant would remain constant, while their weight would be the yield-determining factor. Grain weight would decrease by $12 \%$ in the north, $7 \%$ in the nucleus zone and $21 \%$ in the south, in proportion to the reduction of the grain filling period.

Maize production in the pampean region would be seriously affected as a result of these reductions. The average maize-planted area in the 1980 to 1990 decade was estimated at 2.35 million ha, with a production of 8 million $t$ and $a$ mean yield of $3.4 \mathrm{tha}^{-1}$. The predicted reductions would entail a decrease in total production by $16.5 \%$ (1.32 million $\mathrm{t}$ ). The Junín and Pergamino districts would be the most affected.

\subsection{Soybean}

Soybean yields (Fig. 4) would increase remarkably thoughout the entire pampean region. The largest changes would occur in the south (30 to $60 \%$ ) and the smallest in the north $(10$ to $20 \%)$. As is the case for wheat, the increase would be more significant in the southern districts, where there is a smaller planted area. In the soybean production nucleus zone, which is the same as for maize, increases would be on the order of 20 to $30 \%$. Similar increases have been found in some areas of the USA, where these models were applied by Curry et al. (1995).

Unlike the other crops under study, the duration of the soybean cycle was slightly reduced ( 3 to $4 \mathrm{~d}$ ) in all districts. The reduction in the planting-anthesis stage was larger than in the grain-filling period. This behaviour could be related to the high photoperiodic sensitivity of this crop during the reproductive stage.

The increase in yield results from the production of a larger number of grains per unit area. The development of soy-

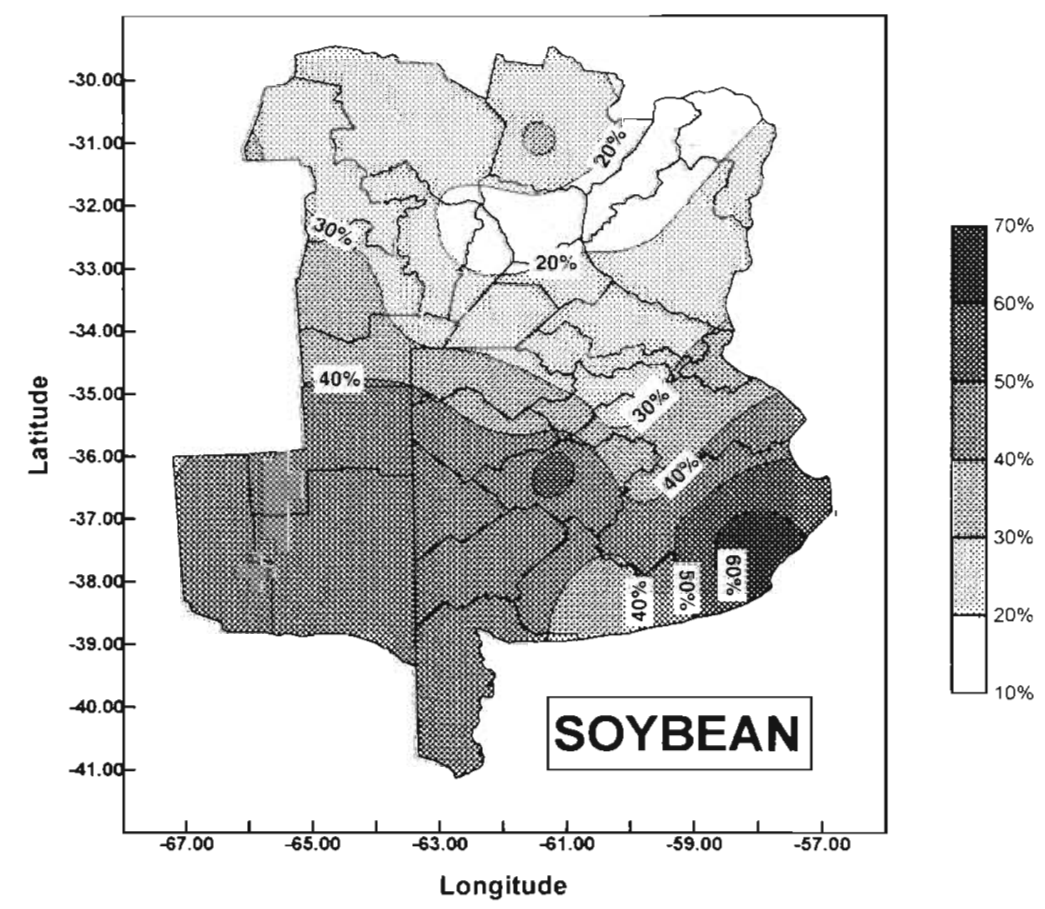

Fig. 4. Differences in percentage between CROPGRO model simulated soybean yields under current and future climate scenarios for the Argentinean pampean region 
bean pods, which is highly dependent on temperature, is slowed down when the night temperature is lower than $22^{\circ} \mathrm{C}$ and is interrupted when it is below $14^{\circ} \mathrm{C}$ (Hesketh et al. 1973, Thomas \& Raper 1978). Thus, the higher temperature values predicted by GISS outputs would enhance the production of a larger number of grains per unit area. This would occur mainly in those zones which are presently colder, e.g. the southeastern sector of Buenos Aires province, where the potential increase in grain number is estimated at $50 \%$.

The production conditions would be remarkably improved as a result of such increases. The planted area in the 1980 to 1989 decade was 2.67 million ha, with a production of 5.43 million $t$ and a mean yield of $2.03 \mathrm{t} \mathrm{ha}^{-1}$. Under a future climate change scenario the production is expected to increase by $20.7 \%$, with a mean yield of $2.45 \mathrm{tha}^{-1}$.

\section{CONCLUSIONS}

The climate changes projected by the GISS model combined with a rise in the $\mathrm{CO}_{2}$ concentration to $550 \mathrm{ppm}$ are expected to cause generalized increases in soybean yield and decreases in maize yield in the Argentinean pampean region. Wheat yields are likely to increase in the southern and western sectors and decrease in the northern sector of the region.

With regard to wheat, the projected variations in yield would be related to the effect of temperature on growth. An increase in yield would occur in areas with day temperatures close to $18^{\circ} \mathrm{C}$ while a decrease would occur in the areas where temperatures are beyond this threshold.

The reductions in maize yields would be associated with a shorter cycle (particularly as regards the reproductive stage), and with the consequent reduction in grain weight.

The highest soybean yields would be due to a rise in temperature during the pod development stage, which would cause an increase in the number of grains per unit area

While wheat and soybean production in the pampean region would increase by 3.6 and $20.7 \%$ respectively, maize production would be reduced by $16.5 \%$.

The climate projections available for this study did not allow for the analysis of information at a more detailed scale. The adaptation of general circulation models to the regional level would enable a better evaluation of the system's vulnerability to the predicted changes.

\section{LITERATURE CITED}

Baethgen WE, Magrin GO (1995) Assessing the impacts of climate change on winter crop production in Uruguay and Argentina using crop simulation models. In: Rosenzweig
C, Allen LH, Harper LA, Holliner SE, Jones JW (eds) Climate change and agriculture: analysis of potential international impacts. Am Soc Agron Spec Publ 59:207-228

Basualdo EM (1995) El nuevo poder terrateniente: una respuesta. Realidad Económica Argentina 132:126-149

Boullon DR, Rodriguez GR, Magrin GO (1996) Aplicaciones de CERES-Maize a la estimación de rendimientos regionales. Actas XXI Reunión Argentina de Fisiología Vegetal, Argentina. Sociedad Argentina de Fisiología Vegetal, Buenos Aires, p 168-169

Curry RB, Jones JW, Boote KJ, Peart RM, Allen LH Jr, Pickering NB (1995) Response of soybean to predicted climate change in the USA. In: Rosenzweig C, Allen LH, Harper LA, Holliner SE, Jones JW (eds) Climate change and agriculture: analysis of potential international impacts. Am Soc Agron Spec Publ 59:163-182

Gallagher JN, Biscoe PV (1978) Radiation absorption, growth and yield of cereals. J Agricult Sci 91:47-60

Gifford RM, Morison JIL (1993) Crop responses to the global increase in atmospheric carbon dioxide concentration. In: Buxton D, Shibles R, Forsberg R, Blad B, Asay K, Paulsen G, Wilson R (eds) International Crop Science I. Crop Science Society of America, Madison, WI, p 325-331

Hansen J, Fung I, Lacis A, Rind D, Lebedeff S, Ruedy R, Russell G, Stone P (1988) Global climate changes as forecast by Goddard Institute for Space Studies three-dimensional model. J Geophys Res 93:9341-9364

Hesketh JD, Myhre DL, Willey CR (1973) Temperature control time intervals between vegetative and reproductive events in soybean. Crop Sci 13:250-254

Hoffman J (1.989) Las variaciones climáticas ocurridas en la Argentina desde fines del siglo pasado hasta el presente. In: El deterioro del ambiente en la Argentina (Suelo-AguaVegetación-Faunal. Servicio Meteorológico Nacional, Fuerza Aérea Argentina, Divulgación No. 15, Buenos Aires

IBSNAT (1994) Decision Support System for Agrotechnology Transfer (DSSAT) version 3.0. University of Hawaii, Honolulu

IPCC (Intergovernmental Panel on Climate Change) (1990) Climate Change, The IPCC Scientific Assessment. Houghton JT, Jenkins GJ, Ephraums JJ (eds). Cambridge University Press, Cambridge, UK

Magrin GO (1994) Aplicaciones de CERES-Wheat en la región pampeana argentina. In: Wall PC (ed) Memorias de la II Reunión Nacional de Trigo y Cereales Menores, Santa Cruz, Bolivia. Centro internacional de mejoramiente de maíz y trigo, Bolivia, p 29-39

Magrin GO, Díaz R, Rebella C, del Santo C, Rodríguez RO (1991) Simulación del crecimiento y desarrollo del trigo en Argentina y la necesidad de intormación meteorológica de entrada. In: Anales VI Congreso Argentino de Meteorologia, Buenos Aires, Argentina. Centro Argentino de Meteorólogos, Buenos Aires, p 49-50

Monteith JL (1981) Climate variation and the growth of crops. Q J R Meteorol Soc 107:749-774

Paruelo JM, Sala OE (1993) Effect of global change on maize production in the Argentinean Pampas. Clim Res 3:161-167

Rodriguez RO, Fernández NR (1993) Cambio climático en la región pampeana argentina y su probable efecto sobre la producción triguera. Rev Invest Agropecu, Argentina $24(1): 83-99$

Rosenzweig C, Hillel D (1995) Potential impacts of climatic change on agriculture and food supply. Consequences, Summer 1995, USA. p 23-32

Thomas JF, Raper CD Jr (1978) Effect of day and night temperatures during floral induction on morphology of soybeans. Agron J 70(6):893-898 